\title{
The Hopkins Transportation Library
}

Jeannette M. Hitchcock is keeper of rare books, Stanford University Libraries, Stanford University, California.

$\mathrm{T}$ RADITION, environment, and association have combined to make Stanford University a singularly appropriate location for a transportation library. The university is but thirty miles south of San Francisco, a center for world transportation and communication. In the years that followed the Spanish discovery of the Golden Gate, the narrow, rock-lined passage into San Francisco Bay, in I775, San Francisco saw clipper ships sail in from around the Horn, and immigrant trains of covered wagons roll in, lured by the promise of golden fortune; then railroads came into being and great transcontinental lines were conceived and built.

Among the many young men to whom the West beckoned were Leland Stanford and Mark Hopkins-names famous in railroad construction annals and equally famous and romantic figures in the history of San Francisco and Stanford University. Both maintained residences on San Francisco's Nob Hill and in the vicinity of what is now Palo Alto. Associated with Collis Potter Huntington and Charles Crocker, these names are preeminent in the railroad history of the West. Not content with transportation supremacy on land, the "Big Four" turned Pacific-wards and in 1874 organized the Occidental and Oriental Steamship Company. Stanford and Hopkins were among the original directors, the former serving as president before his death in 1893 , while Mark Hopkins, the financial genius of the group, was the company's first treasurer.

It is small wonder, then, that Timothy Hopkins, brought as a small boy into such an environment, should develop a keen interest in railroads. Born Timothy Nolan at Augusta, Maine, in I859, he came a few years later to Sacramento where $\mathrm{Mr}$. and Mrs. Mark Hopkins were then living. So interested did they become in the lad that he was taken into the family and given the name of Timothy Hopkins, although actual adoption was delayed until after the death of Mark Hopkins in 1878 . At the time of Mark Hopkins' death, Timothy was assistant treasurer to the Southern Pacific Company. Much of the routine work of the office had been turned over to him, so that at twenty-four years of age he was well prepared for the promotion that made him treasurer. Four years later, Leland Stanford appointed him to the original board of trustees of Stanford University with life tenure. Until his death on January I, 1936, Timothy Hopkins maintained a keen and benevolent interest in the affairs of the university.

\section{Origin of the Collection}

Interest in the railroads of the Pacific coast and in the relations of transportation industries to the public led Timothy Hopkins, while acting as treasurer of the Southern Pacific Company, to form gradually a private library of railroadiana 
which included the most important works on railroad economics and administration. In I 883 his collection was augmented by the acquisition of the valuable library relating to the railroads of Great Britain assembled by Frederick Broughton during the thirty-four years he was connected with railways in both England and Canada.

Realizing the usefulness of having such a collection in a university, Mr. Hopkins decided to give his library to Stanford University and to make ample provision for its permanent maintenance and growth. Accordingly, in the spring of 1892 , the gift of nearly two thousand books and pamphlets was made. This formed the nucleus of the Hopkins Railway Library, as it was then called.

Mr. Hopkins likewise recognized the growing importance of railroads. It was his intention to acquire all subjects pertaining to railway interests-the literature of theory and economics, the literature of construction and operation. The collection was to be useful alike to the railroad official and to the student of those economic problems associated with transportation.

At the time of presentation, the collection was probably unique. It was widely publicized through Mr. Frederick J. Teggart's Catalogue of the Hopkins Railway Library ${ }^{1}$ published in 1895 . By this time the collection had grown to nearly ten thousand volumes and pamphlets, but from then on its growth was not so meteoric. Mr. Hopkins gradually withdrew his financial support but there has always been a small annual appropriation, entirely inadequate, from library funds.

In 1935, a year before his death, Mr.

${ }^{1}$ This Catalog was issued as Publications. [no.] 1 by Leland Stanford Junior University Library.
Hopkins suggested a change of name to enable the library to enlarge its scope to include the history, economics, and engineering aspects of all forms of transportation and communication-not railroads only, but also highways, airways, waterways, pipe lines, communication, postal, and express service. In accordance with his wish the name was changed to the Hopkins Transportation Library. Again Mr. Hopkins provided generously for the maintenance and growth of the librarythis time in his will-although the funds are not yet available.

\section{Outstanding Items in the Collection}

In the original collection the outstanding features were probably the British Parliamentary papers and the books and pamphlets relating to the Pacific railroads. But the library was general in scope, containing biographies, novels, and poetry; bibliographies, dictionaries, periodicals, and society publications; special works relating to Africa, Asia, Europe, Oceanica, and the American continents; and treatises on railway economics, tariffs, transport, legislation, construction, rolling-stock, traffic, subsidiary railroads, and state ownership with its allied questions. It was relatively rich in the early literature of the subject, in the early history of English and American railroads and in early reports of railway companies and state railroad commissioners.

The acquisition of the Broughton collection brought a splendid file of British sessional papers which, with those in our document division, form a very complete set.

The advent of railroads precipitated many new questions. This is evident in the voluminous reports found in the English section of the library-reports on ac- 
cidents, signal arrangements, brakes, locomotives, . railway acts pertaining to England, Scotland, and Ireland, conveyance of mails, railway bills and agreements, atmospheric and narrow gauge railway rules, legislation amalgamation; there are also twenty-three volumes of railway tracts. The develop!nent of the Railway Department of the Board of Trade can be traced through the select committees in Parliament which dealt with the first problems requiring legislative consideration, to the commissions of a more permanent nature.

In manuscript form the collection contains the minutes of the Railway Clearing House, London, April 26, I 842-December I6, I85I. These include the minutes of the general managers, goods managers, superintendents, and railway officers. The greater portion are signed by $\mathrm{K}$. Morison as secretary.

Another interesting item is Jonathan Hulls' $A$ Description and Draught of a New-Invented Machine for Carrying Vessels or Ships out of, or into any Harbour, London, I737. Hulls was the first person who attempted in a practical way to employ steam in propelling a vessel in water.

\section{Railway Guides}

Soon after the introduction of railroads into England, George Bradshaw began to publish a series of railway guides. The first of these, published in London in 1839, is Bradshaw's Railway Time Tables and Assistant to Railway Travelling, with Illustrative Maps and Plans. The following year, 1840, the title was changed to Bradshaw's Railway Companion. December, I84I, found $\mathrm{Mr}$. Bradshaw issuing time tables for each month under the title of Bradshaw's
Monthly Railway Guide. Other Bradshaw items include a considerable file of Bradshaw's Railway Manual, Shareholder's Guide, and Official Directory from I 848 to I 90 I.

In the earlier days of railroading there were published certain guidebooks which, in their way, are quite comparable to the Muirheads of today. Sometimes they were merely folders, but others were sizeable books running to nearly six hundred pages. There were the official illustrated guides of the various railroads with charming illustrations; and there were others with more alluring titles such as Sir Henry Cole's Railway Chronicle Travelling Charts; or, Iron Road Books, for Perusal on the Journey; in which Are Noted the Towns, Scenery and Natural History, Antiquities and Historical Associations, Passed by the Line of Railway.

From France, Germany, Switzerland, and Italy we likewise find works dealing with the construction of railroads, reports from individual roads and governmental bodies, economic treatises, law, and periodicals. There is an interesting file of fifty-five volumes dealing with the St. Gothard railway.

\section{American Material}

In the American field, with the exception of a few undated pamphlets, the earliest imprint is The American $M e$ chanics' Magazine, vol. I, I825. While not devoted particularly to transportation, it does contain interesting material concerning early railroads. The second is William Strickland's Reports on Canals, Railways, Roads, and Other Subjects, Made to "The Pennsylvania Society for the Promotion of Internal Improvements," Philadelphia, I826.

(Continued on page 75) 
Mohrhardt, chairman, was editor of $A$ List of Books for Junior College Libraries published by the American Library Association in 1937. A supplementary compilation is desired to extend this list, especially in the

\section{The Hayes Memorial Library}

\section{(Continued from page 59)}

sideration a project to put on film bibliographies that have proved uneconomical to publish in the usual way. Many of these are in the hands of individual compilers, institutions, societies, and such agencies as the Historical Records Survey. Only those in the field of Ameri- direction of vocational and semiprofessional education.

The Commission on Junior College Terminal Education is a subsidiary of the American Association of Junior Colleges.

can history will be considered, and the work could only be done on the understanding that the films would be made available to libraries and scholars, generally on the basis either of loan or sale. Suggestions and comments on the project are earnestly invited.

\section{The Hopkins Transportation Library}

\section{(Continued from page 62)}

In 1870 the Board of Immigration of Iowa issued Iowa, die Heimath für Einwanderer. This was also published in English and Dutch. In the Stanford copy of the German edition is laid a leaf addressed (in German) to all Germans who wish to come to America, and signed by Ebenezer Cook, vice-president and landcommissioner of the Chicago, Rock Island and Pacific railroad. On the recto of this leaf is a map showing the route from Chicago to Council Bluffs.

Probably the most outstanding item of the Pacific railroads material is the report of the chief engineer, William J. Lewis, of the Pacific and Atlantic railroad company dated December I3, I85I. This report is accompanied by a folded map of the route between San Francisco and San Jose as located by Mr. Lewis, SeptemberNovember, I85I.

There are also extensive manuscript correspondence files of Mark Hopkins dating from I 863-I885 dealing with the Central Pacific, Western Pacific, and Southern Pacific railroads in matters of construction and administration. These include a large file of letters from Collis P. Huntington.

The comment may be made that emphasis has been placed on the earlier literature. It is true that the demand is more likely to come for contemporary material, but the historical background must not be neglected.

That there is interest in historical material is shown in Mr. Thomas R. Thomson's Check List of American Publications on Railroads before $I 84 I$, galley sets of which several university and private libraries received for checking. It is to be hoped that the publication of this will prompt the compilation of similar check lists on canals, bridges, roads, etc. 